Trends in Horticulture (2018) Volume 1

doi: $10.24294 /$ th.v1i2.914

\title{
Analysis of Trend in Area, Production and Yield of Major Vegetables of Nepal
}

\author{
Deepak Ghimire ${ }^{\mathbf{1}}$, Gunakeshari Lamsal ${ }^{1}$, Bindu Paudel $^{\mathbf{2}}$, Sushila Khatri ${ }^{1}$, Bandana Bhusal ${ }^{\mathbf{1}}$ \\ ${ }^{1}$ Institute of Agriculture and Animal Science (IAAS), Tribhuvan University, Nepal \\ ${ }^{2}$ Agriculture and Forestry University (AFU), Chitwan, Nepal
}

\begin{abstract}
Vegetable production is an important sector of economy for farmers in Nepal. The analysis was carried out to explore the trends in vegetable production sector in Nepal along with the recent trend of some major vegetables in terms of area, production and yield. The time series data from 1977/78 to 2016/17 (40 years) of vegetables production and 5 years data (2011/12 - 2015/16) of major vegetables were collected from reliable source and analysis was done through Microsoft Excel. The results show that between 1977/78 and 2016/17 the area under vegetables cultivation has jumped by $222.8 \%$ while production is increased by $728.21 \%$ and productivity is increased by $156.6 \%$ during this course. The result also reveals that during the period of 5 years (2011/12 - 2015/16), solanaceous and cruciferous vegetables has an increasing trend in area, production and yield except for the area under cultivation for eggplant (declined by 5.2\%) and for radish (declined by 6.0\%) respectively while cucurbitaceous vegetables has increasing trend in area and production but an declining trend in yield except for the yield of cucumber (increased by 15.8\%). However, the trend of other major vegetables is seen highly fluctuating over the years.
\end{abstract}

Keywords: Horticulture; Vegetables; Trend; Nepal

\section{Introduction}

With 65.1 percentage of people engaged, agriculture contributes 31.23\% to National Gross Domestic Product (GDP) where horticulture sub-sector has the most significant role sharing 21.42 percent $^{[1]}$. Vegetable production alone contributes around $9.71 \%$ to total Agricultural GDP ${ }^{[2]}$. Vegetable farming has been widely adopted by the people across the country as a part of their employment. Vegetable farming in Nepal is not only the mainstay of its economy but also way of life of rural farmers. In the year 2016/17, the total cultivated area of the country is about 3.09 million hectare, among which vegetable crops occupy $9.19 \%$ of total cultivated agricultural land and the annual vegetable production was found to be $38,59,492$ metric ton with average productivity of $13.5 \mathrm{Mt} / \mathrm{ha}^{[3]}$. The average productivity of vegetables from $1991 / 92$ to $2015 / 16$ was $11.09 \mathrm{Mt} / \mathrm{ha}^{[4]}$.

In terms of export, vegetable is the fifth important agriculture product behind Lentil (29.6\% of agricultural exports), cardamom (7\%), wheat (6.7\%), and tea ${ }^{[5]}$. In 2015/16, Nepal imported edible vegetables and certain roots and tubers worth NPR 17,958,156,000 and exported them worth NPR 1,606,611,000 with a trade balance of $-16,351,545,000^{[6]}$. This shows that there is good potential for import replacement in vegetables. Similarly, the demand for vegetables is increasing at higher rate with increasing rate of population. Rising incomes are changing food demand from cereals towards more vegetables and fruits consumption.

It has been of high importance to increase the vegetable production with the limitation of land available for cultivation. Realizing the importance of production potential and increasing demand of vegetables, several programs have been conducted to promote commercial vegetable farming. Agriculture Perspective Plan (APP, 1995-2014) had targeted the growth rate of horticulture GDP to 5.5 percent per annum by 2014/2015 and growth rate of vegetable GDP in particular to 5.42 percent per annum ${ }^{[7]}$. In order to come up with targeted growth rate of the agriculture, APP mainly emphasized on the production of high value crops through the pocket packages strategy on crops and horticulture crops

Copyright (C) 2018 Deepak Ghimire et al.

doi: $10.24294 /$ th.v1i2.914

EnPress Publisher LLC.This work is licensed under the Creative Commons Attribution-NonCommercial 4.0 International License (CC BY-NC 4.0). http://creativecommons.org/licenses/ by/4.0/ 
in different areas of different ecological zones. Similarly, under the outcome Profitable Commercialization, ADS has highlighted enhancing development of the vegetables value chain through production, marketing and policy/institutional support as an important activity. The strategy has prioritized a limited number of value chains over the first five years and vegetable sector is one among the top five sectors ${ }^{[8]}$.

However, insufficient study on analysis of the recent trends of vegetable production in the country has constricted the efficient planning and program development in this sector. Thorough observation of the pattern of growth of vegetable sector over time to assess whether it has used the investments efficiently to achieve the maximum/optimum production is important. As the sector plays significant role for the country's economy, it is a foremost requirement to identify the time periods where insufficient growth has been experienced and further study on the respective government policies and programs should be made. The present study was conducted with a view to analyze trends in area, production and yield of vegetables in Nepal over the past 40 years. Further, the study was undertaken to assess the growth pattern in the context of total cultivated area, production and yield followed by some economically important vegetables of the country during the period of five years (2011/12 to 2015/16).

\section{Materials and Methodology}

The time series secondary data for area, production and productivity for vegetables in hectare, metric ton and kilogram/hectare of total 40 years (from 1977/78 to 2016/17) were extracted from publications of Vegetable Development Directorate and data of major vegetables selected on the basis of family were collected from the data book published by Ministry of Agriculture Development (MoAD) for 5 years period from 2011/12 to 2015/16.

Linear trend analysis model was used to analyze time series data of area, production and productivity of vegetables in Nepal. The statistical analysis of area, production and yield scenario was carried out through Microsoft excel program. Line graphs were prepared using MS Excel to interpret the results. Annual average yield of vegetables was calculated as:

AAY (Annual average yield) of vegetables $=$ (Production of 1977/78+ Production of $1978 / 79+$. +Production of 2016/17)/ (Area of 1977/78+ Area of 1978/79+ Area of 2016/17).

\section{Results and Discussion}

\subsection{Vegetable production trend in Nepal}

On analyzing the area, production and yield of overall vegetable sector over past 40 years (1977/78 - 2016/17), the trend of area under cultivation, production and yield of vegetables is increasing over time (Fig. 1). Its cultivation area has jumped by $222.8 \%$ between $1977 / 78$ and $2016 / 17$ while production is increased by $728.21 \%$ and productivity is increased by $156.6 \%$ during this course. The area under cultivation is continuously increasing every year with a varying rate except for the years 1998/99 and 2015/16 where it has decreased than the previous year. Similar is the trend in production scenario of vegetables, which is continuously increasing each year with a varying rate except for the years 1980/81 and 1998/99 where it has decreased than the previous year. Over the years (1977/78 - 2016/17), the yearly average area under vegetables cultivation is 167558.45 ha and the yearly average production is $1705066.25 \mathrm{Mt}$ with a yearly average yield of 10.2 Mt/ha. In Figure 1, the R square value for the production and area trend line is 0.924 and 0.880 respectively which are closer to 1 . This signifies that the trend line is more accurate to the data. 


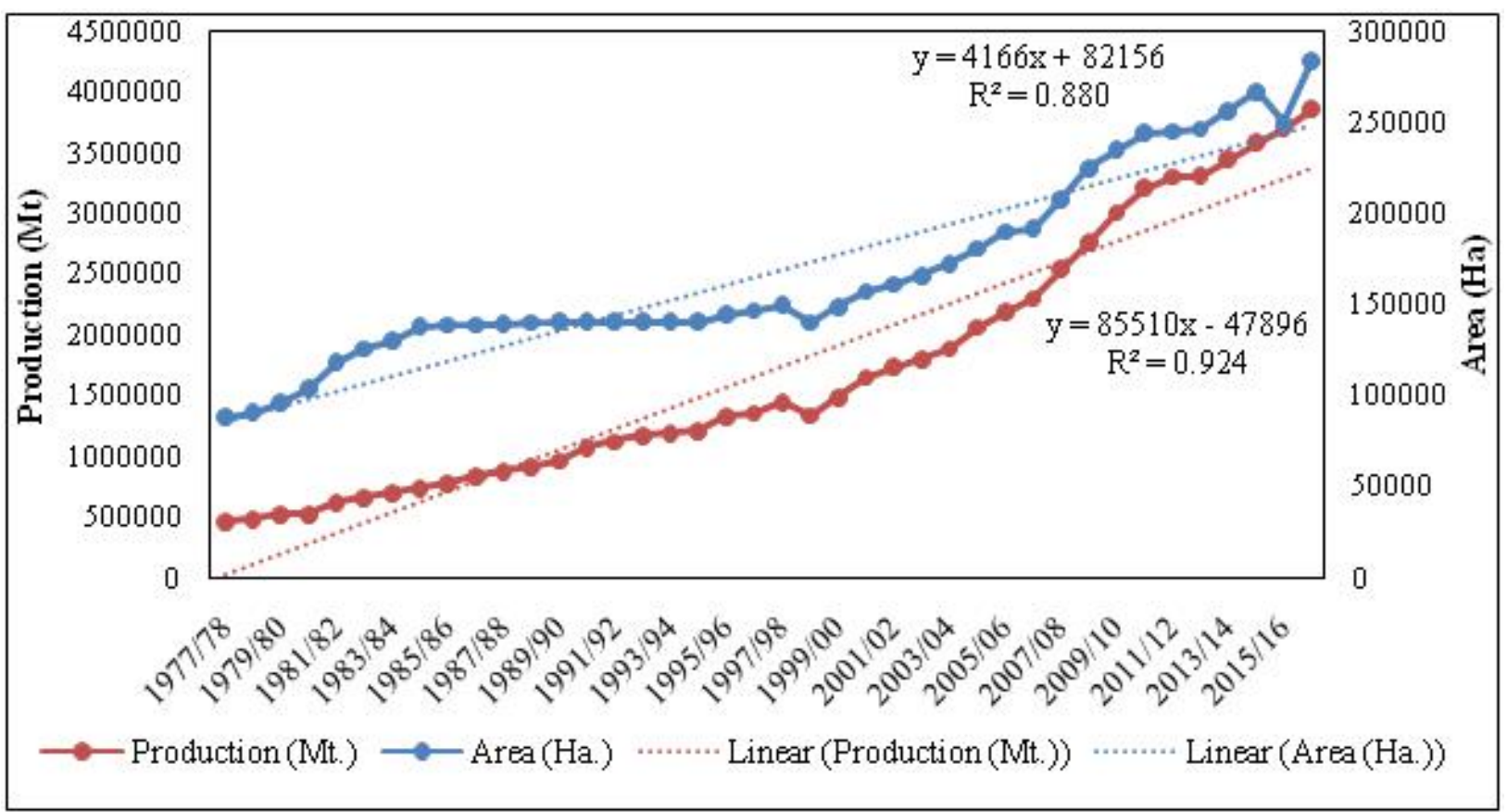

Figure 1; Vegetable production trend in Nepal.

(Source: Vegetable Development Directorate 2014/15 and MoAD 2017/18)

\subsection{Production trend of Major Vegetables of Nepal (2011/12 - 2015/16)}

\subsubsection{Solanaceous vegetables}

Among the different solanaceous vegetables grown in Nepal, tomato, eggplant, chilli and capsicum are the major ones and are considered under the study. In the year 2015/16, this group shares $15.8 \%$ of total area (39491 ha) and $16.8 \%$ of total production $(623154.6 \mathrm{Mt})$ of vegetables in the country whereby tomato has the highest share of 8.0 percent in area under cultivation (20046 ha) and 10.5 percent in total vegetables production of the country (386824.6 Mt). During the period of 5 years (2011/12 - 2015/16), each vegetables of this family has an increasing trend in area, production and yield except for the area under cultivation for eggplant which has declined by 5.2\% (Fig. 2,3,4).

The area under cultivation of solanaceous vegetables is moreover increasing every year with a varying rate except for; tomato in 2013/14 where it has declined by 12.4\% than the previous year, eggplant and chilli in 2013/14 with decline percentage of 10.0 and 13.9 respectively, capsicum in the year 2014/15 with decline percentage of 15.5 and eggplant in the year 2015/16 with decline percentage of 6.0. Similar is the trend in production scenario, which is increasing each year with a varying rate except for; chilli in 2012/13 (declined by $3.9 \%$ than the previous year), tomato and eggplant in 2013/14 with decline percentage of 22 and 4.1 respectively, capsicum in 2014/15 with decline percentage of 19 and eggplant in 2015/16 with decline percentage of 2.6. 


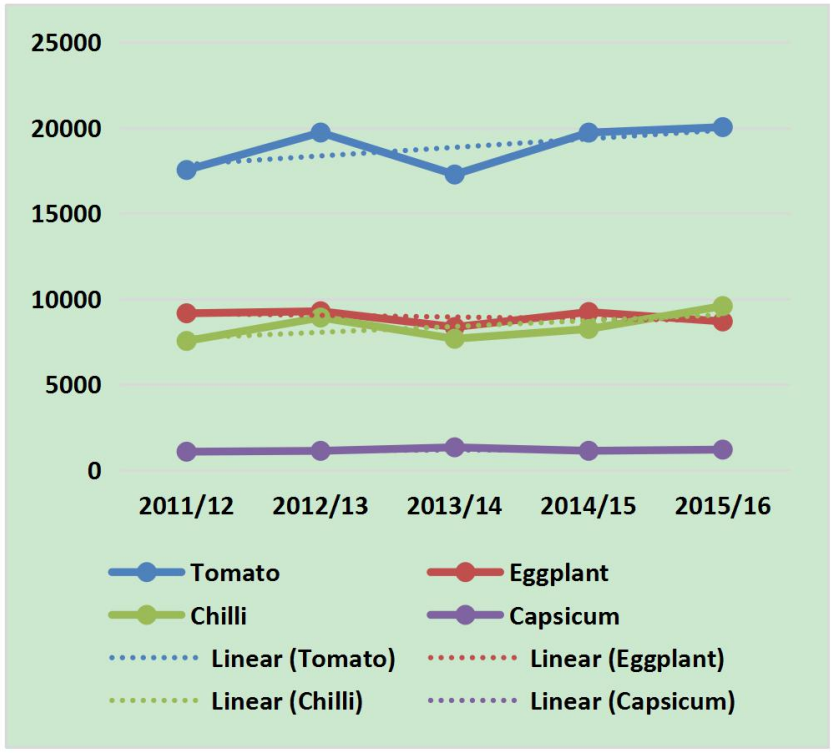

Figure 2; Trend in area cultivated for major solanaceous vegetables (2011/12-2015/16).

(Source: MoAD 2011/12 to 2015/16)

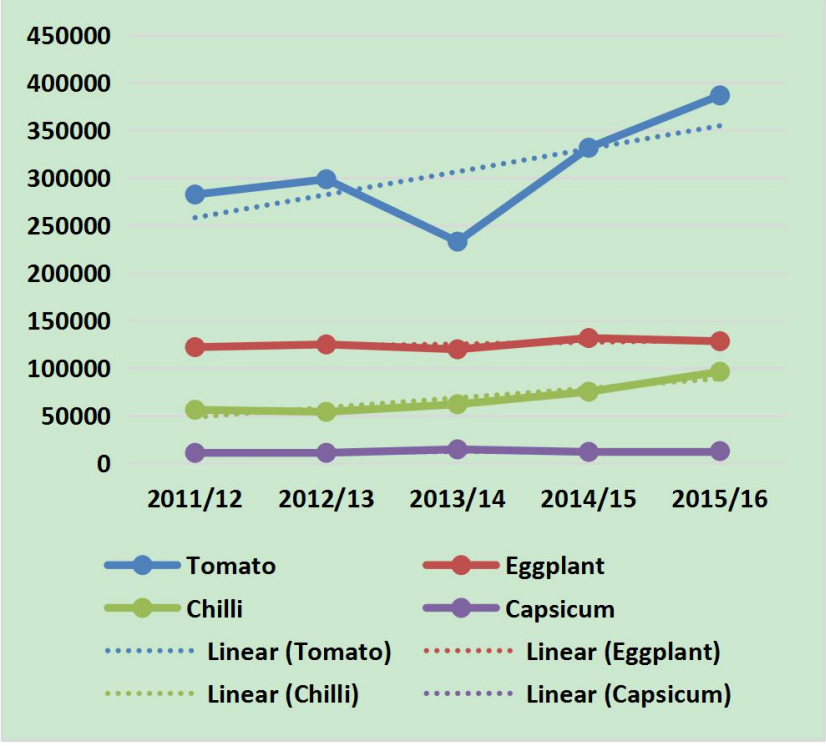

Figure 3; Trend in production of major solanaceous vegetables (2011/12-2015/16).

(Source: MoAD 2011/12 to 2015/16)

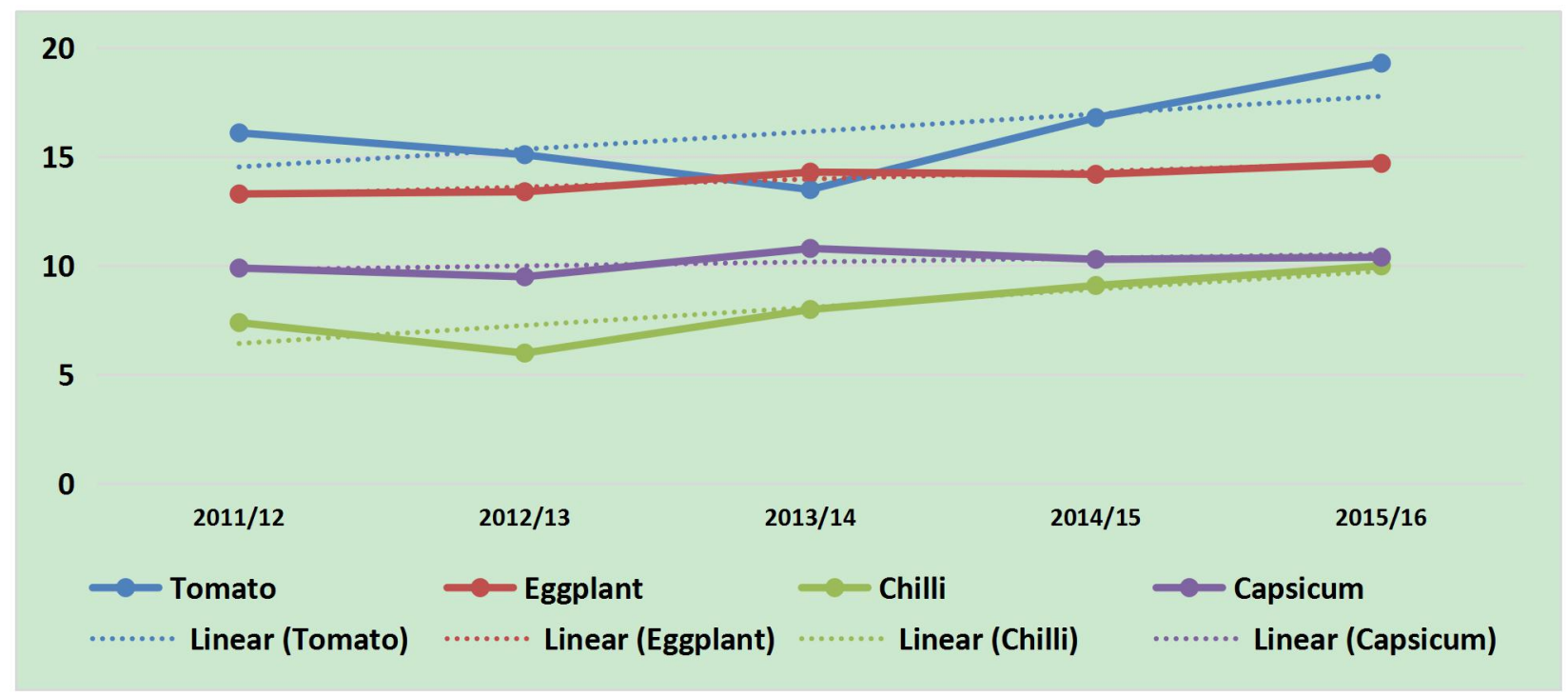

Figure 4; Trend in yield of major solanaceous vegetables (2011/12-2015/16).

(Source: MoAD 2011/12 to 2015/16)

The trend in yield of the solanaceous vegetables shows that the yield for tomato has decreased in the years 2012/13 and $2013 / 14$ (by $6.0 \%$ and $10.9 \%$ than the previous year respectively) and increased thereafter by $24.7 \%$ and $14.7 \%$ in $2014 / 15$ and $2015 / 16$ respectively with an overall rise by $19.8 \%$ since $2011 / 12$ to $2015 / 16$. There has been a decline in yield of chilli and capsicum in 2012/13 and decline in yield of eggplant and capsicum in 2014/15 while the yield is in increasing trend in other years.

\subsubsection{Cruciferous vegetables}

Among the different cruciferous vegetables grown in Nepal, cauliflower, cabbage and radish are the major ones and are considered under the study. In the year 2015/16, this group shares 32\% of total area (79954.1 ha) and 35.1\% of total production (3700969 Mt) of vegetables in the country whereby cauliflower has the highest share of 14.0 percent in area under cultivation (34967 ha) and 14.9 percent in total vegetables production of the country (550044.8 Mt), which is the highest among all the vegetables. During the period of 5 years $(2011 / 12$ - 2015/16), each vegetables of this family has an increasing trend in area, production and yield except for the area under cultivation for radish which has 
declined by $6.0 \%$ (Fig. $5,6,7$ ).

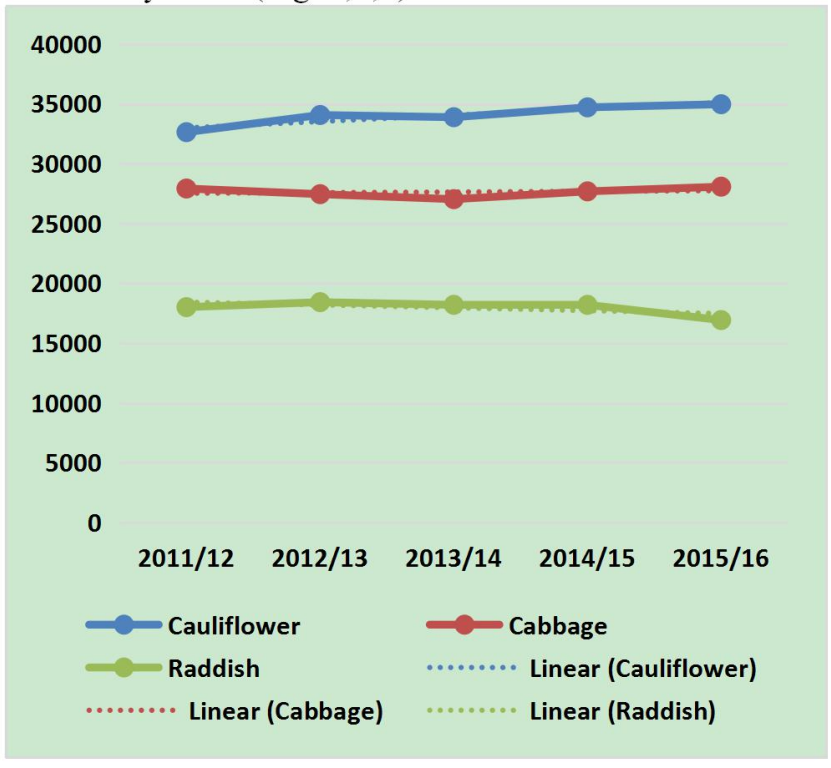

Figure 5; Trend in area cultivated for major cruciferous vegetables (2011/12-2015/16).

(Source: MoAD 2011/12 to 2015/16)

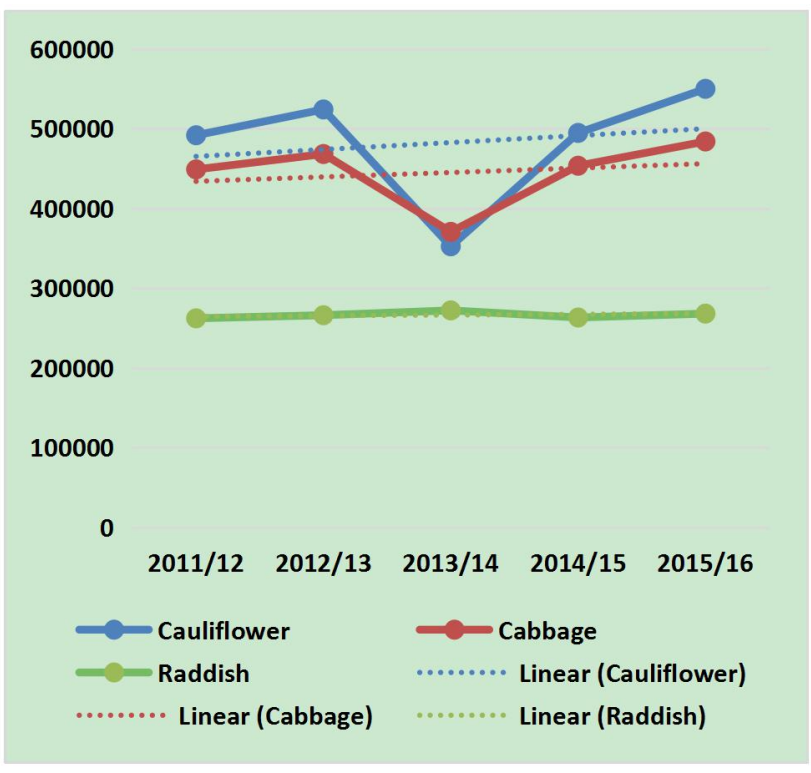

Figure 6; Trend in production of major cruciferous vegetables (2011/12-2015/16).

(Source: MoAD 2011/12 to 2015/16)

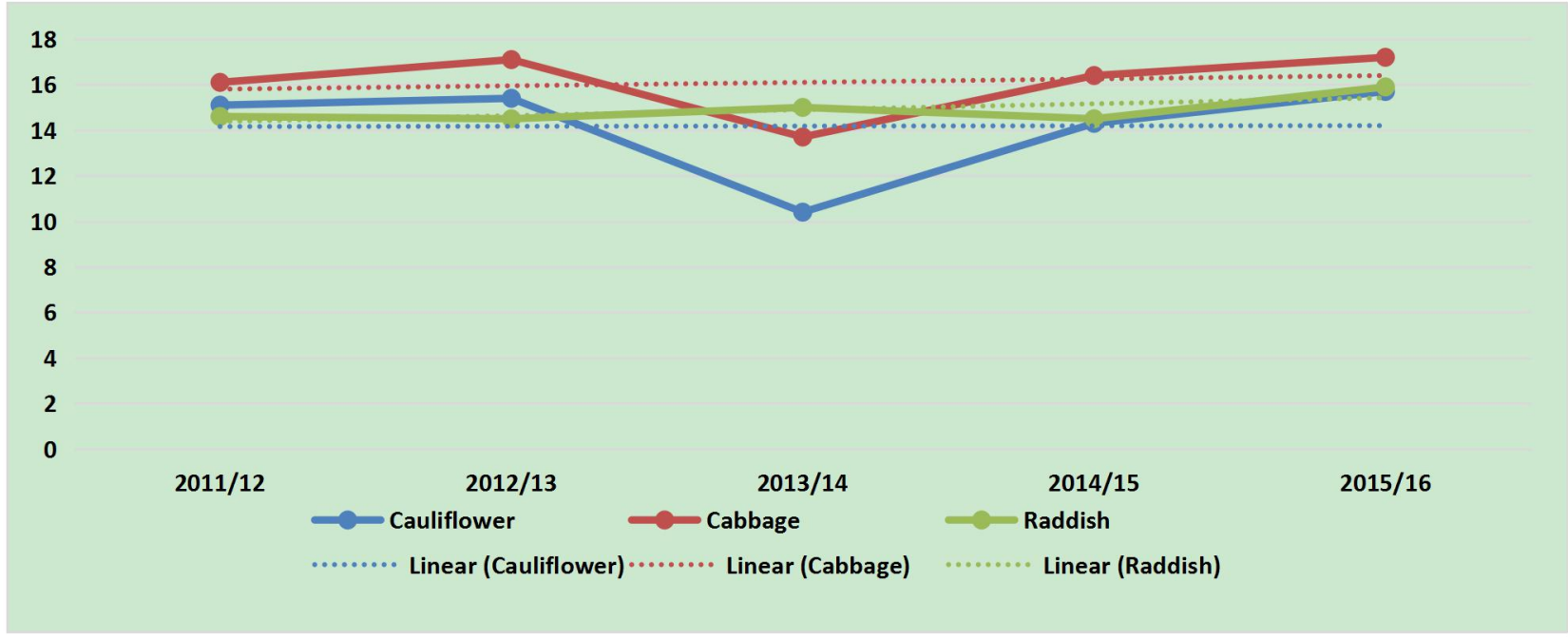

Figure 7; Trend in yield of major cruciferous vegetables (2011/12-2015/16).

(Source: MoAD 2011/12 to 2015/16)

There has been decline in production of cruciferous vegetables (32.7\% in cauliflower and $20.8 \%$ in cabbage) in the year 2013/14 along with decline in area under cultivation ( $0.5 \%$ in cauliflower and $1.5 \%$ in cabbage) and decline in yield (32.4\% in cauliflower and $19.6 \%$ in cabbage). However, the area, production and yield of cauliflower and cabbage have increased in the recent years. The area under cultivation for radish has declined from 18415 ha in 2012/13 to 16915.7 ha in 2015/16 while the production and yield are increasing except for the year 2014/15 where there is a decline of $3.3 \%$ in both production and yield.

\subsubsection{Cucurbitaceous vegetables}

Among the different cucurbitaceous vegetables grown in Nepal, bottle gourd, bitter gourd, cucumber, and pumpkin are the major ones and are considered under the study. In the year $2015 / 16$, this group shares $14.1 \%$ of total area (35293.9 ha) and $14.16 \%$ of total production of vegetables in the country $(524359.6 \mathrm{Mt}$ ) whereby bitter gourd has the 
highest share of 4.0 percent in area under cultivation (10082.2 ha) and cucumber has the highest share of 4.3 percent in total vegetables production of the country (159041.8 Mt). On analysing recent 5 years $(2011 / 12$ - 2015/16) trend of major cucurbitaceous vegetables, each vegetable has an increasing trend in area and production while there is an declining trend in yield of all vegetables except for the yield of cucumber which was increased by 15.8\% (Fig. 8,9,10).

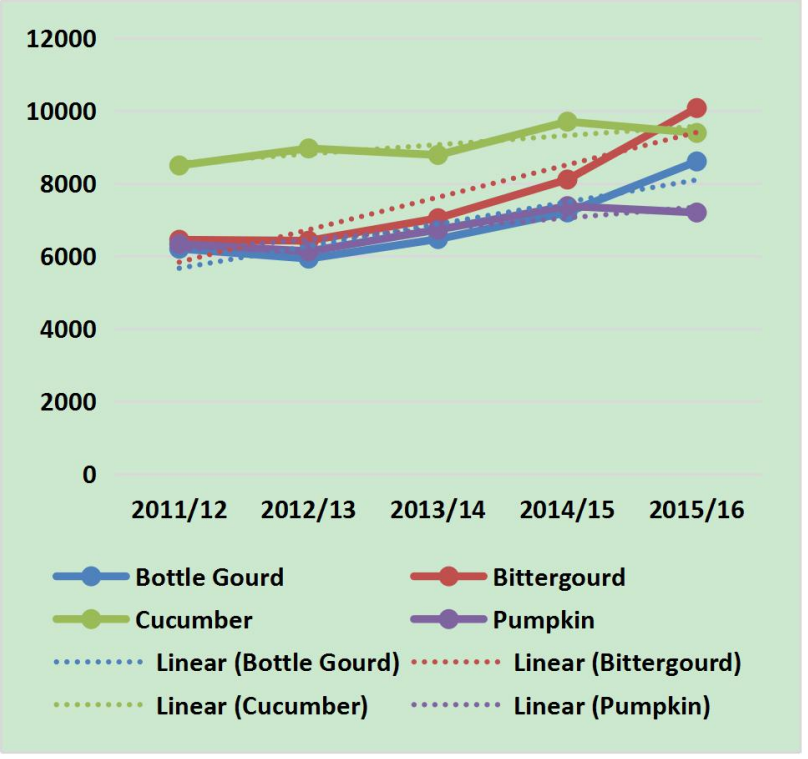

Figure 8; Trend in area cultivated for major cucurbitaceous vegetables (2011/12-2015/16).

(Source: MoAD 2011/12 to 2015/16)

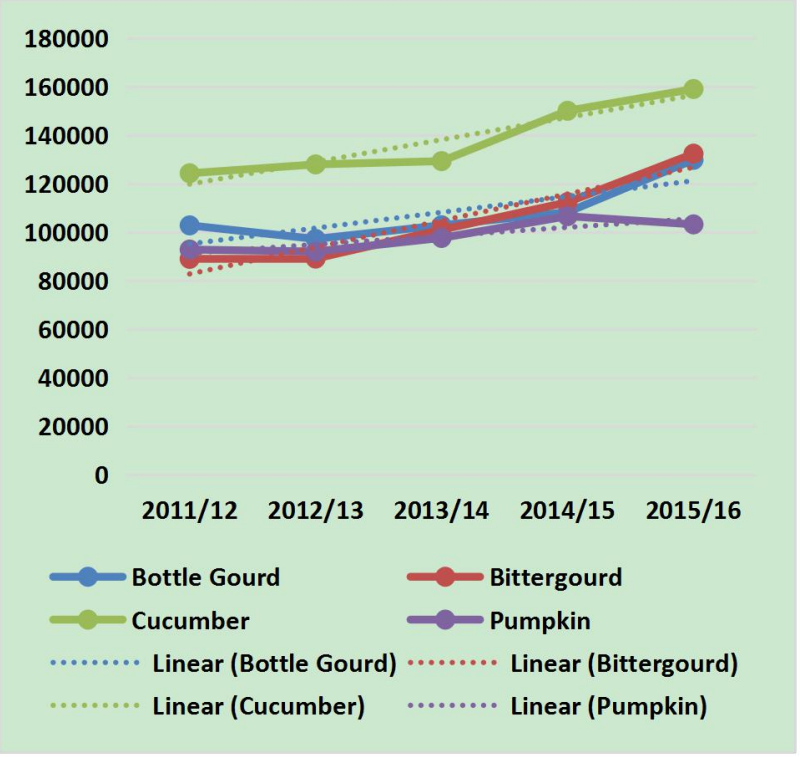

Figure 9; Trend in production of major cucurbitaceous vegetables (2011/12-2015/16).

(Source: MoAD 2011/12 to 2015/16)

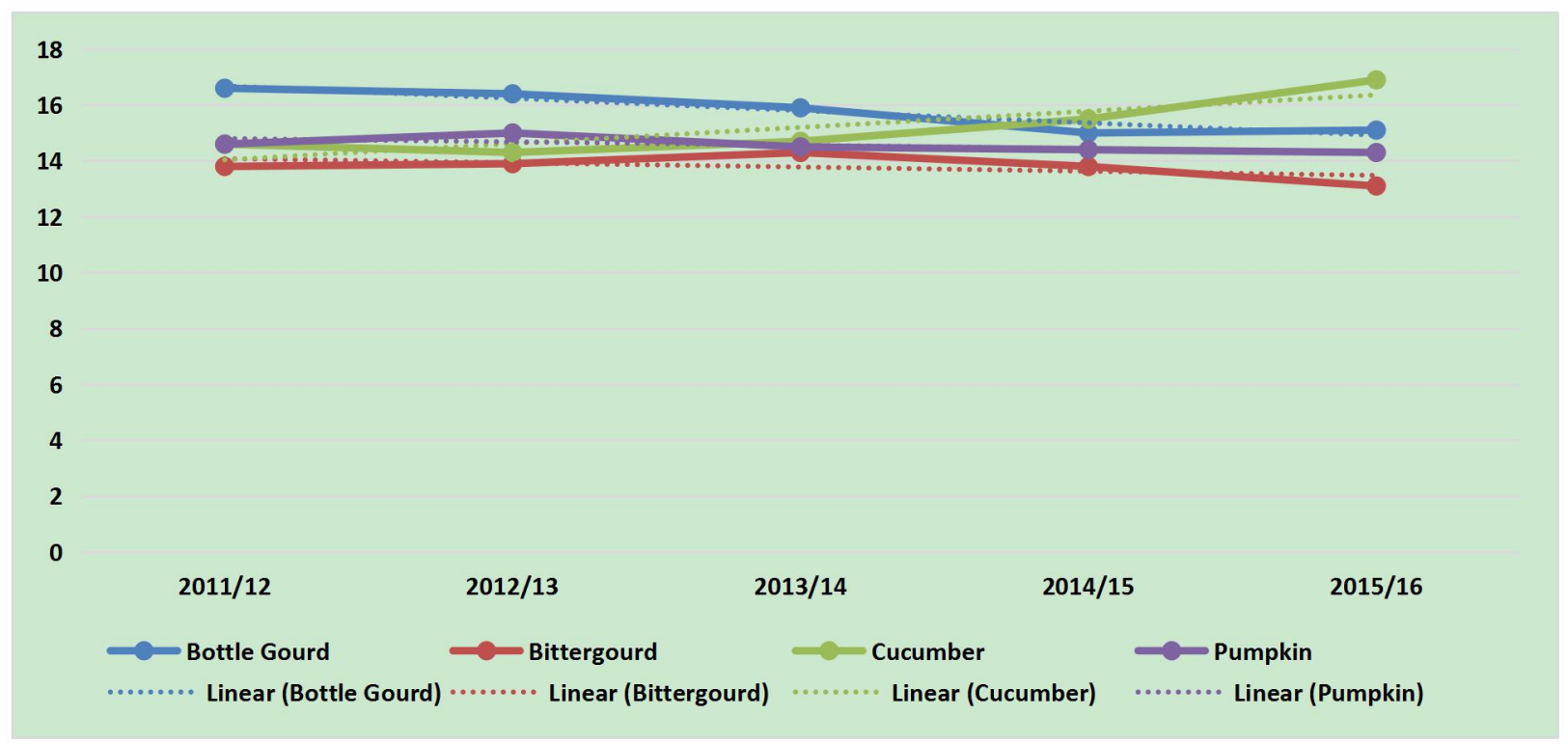

Figure 10; Trend in yield of major cucurbitaceous vegetables (2011/12-2015/16).

(Source: MoAD 2011/12 to 2015/16)

The area under cultivation of cucurbitaceous vegetables is moreover increasing every year with a varying rate, except during the year of 2012/13 where area for bottle gourd, bitter gourd and pumpkin has declined by the percentage of 4.4, 0.4 and 3.2 respectively. The area under pumpkin cultivation for the year 2015/16 declined with the percentage of 2.4. Similarly, cucumber cultivation area declined in the year 2013/14 and 2015/16 by 2 and 3.2 percentages respectively. Similar is the trend in production scenario, which is increasing every year with a varying rate, except during the year 2012/13 where production for bottle gourd and pumpkin is declining with 5.4 and 0.9 percentage. In $2015 / 16$, the production of pumpkin decreased by 3.2 percentage than previous year. 
The trend in yield of the cucurbitaceous vegetables shows that the yields for all the crops are declining. But in the year of 2015/16 the yield of bottle gourd increased by only 0.4 percentage. In the year of 2012/13 the yield of bitter gourd and pumpkin was increased by 0.6 and 2.4 percentage respectively, whereas for cucumber the yield is increased in every year except in 2012/13 with declining percentage of 2.5 .

\subsubsection{Other vegetables}

Based on the higher percentage share in area and production, major vegetables of family Amaryllidaceae (onion, garlic), Leguminosae (cowpea, French bean) and okra from family Malvaceae are included under study as other vegetables. On analyzing 5 years $(2011 / 12$ - 2015/16) trend of above vegetables, each vegetables trend is seen highly fluctuating.

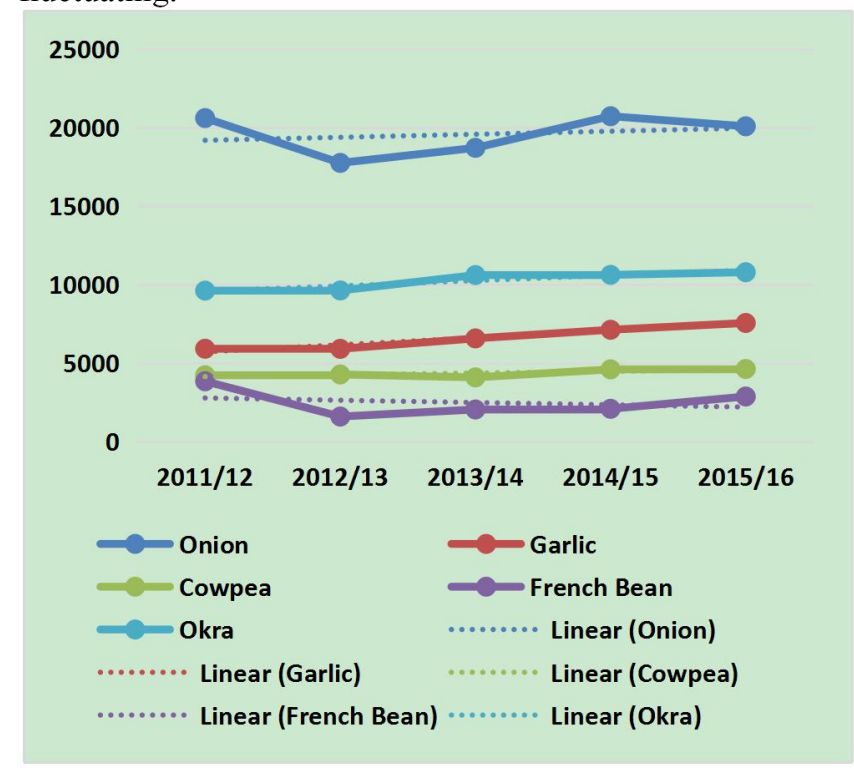

Figure 11; Trend in area cultivated for other major vegetables (2011/12-2015/16).

(Source: MoAD 2011/12 to 2015/16)

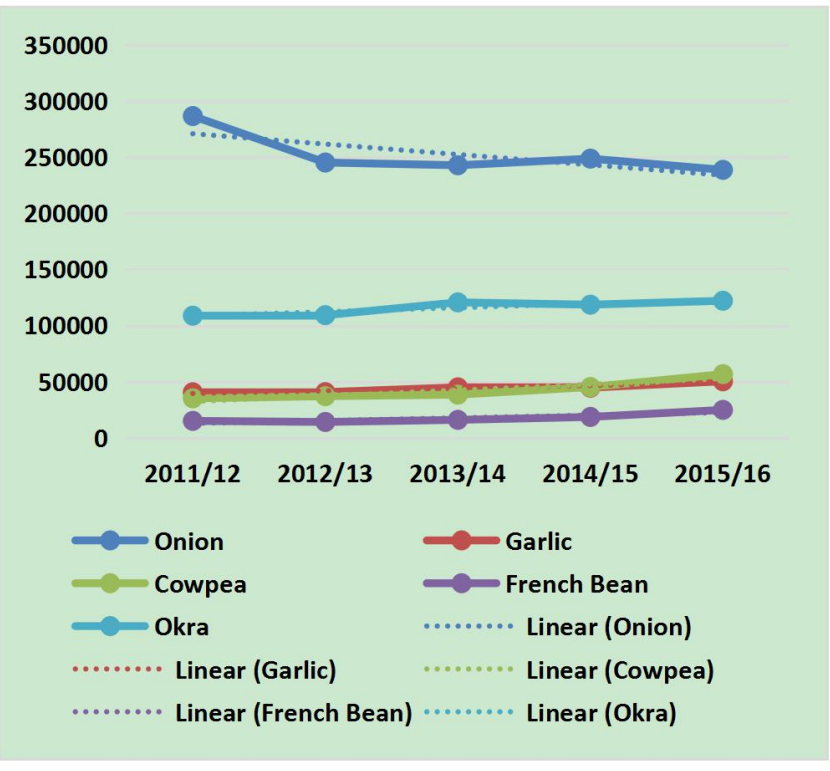

Figure 12; Trend in production of other major vegetables (2011/12-2015/16).

(Source: MoAD 2011/12 to 2015/16)

For onion, the overall trend is decreasing where area, production and yield has declined by $2.5 \%, 16.7 \%$ and $14.5 \%$ respectively. However, in the year of 2013/14 and 2014/15 area of onion is in increasing trend with percentage of 5.4 and 10.8 respectively and in the year of 2014/15 production of onion is increasing by $2.4 \%$. For garlic, area and production has increased by $27.7 \%$ and $24.1 \%$ respectively while the yield has declined by $2.8 \%$ over the 5 years. Similar is the case with okra where the area and production has increased by $12.2 \%$ each while yield has declined by $0.2 \%$. For cowpea, the area, production and yield has increased by $9.4 \%, 61.2 \%$ and $47.4 \%$ respectively with $4.4 \%$ decline in area in year 2013/14. The area under cultivation for French bean has declined by $25.3 \%$ while production and yield has increased by $64.4 \%$ and $120.1 \%$ respectively. However, there is a decline in yield in $2015 / 16$ by $2.9 \%$ attributed by the greater increase in area than the production. 


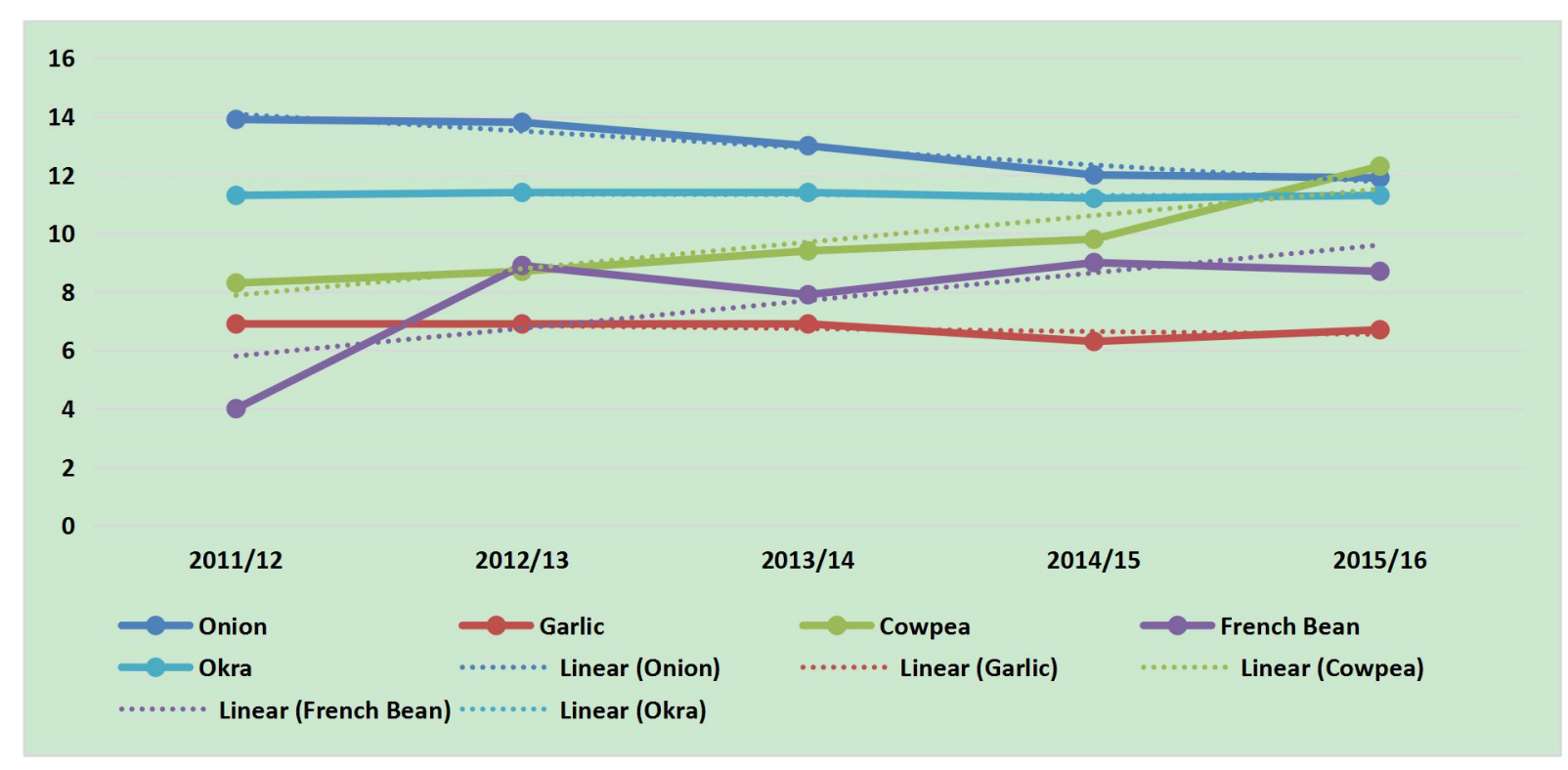

Figure 13; Trend in yield of other major vegetables (2011/12-2015/16).

(Source: MoAD 2011/12 to 2015/16)

\section{Conclusion}

Over the past 40 years (from 1977/78 to 2016/17), the vegetables cultivation area has jumped by $222.8 \%$ while production has increased by $728.21 \%$ and productivity has increased by $156.6 \%$ during this course. The area under cultivation of vegetables is continuously increasing every year with a varying rate except for the years 1998/99 and 2015/16 where it has decreased than the previous year. Similar is the trend in production scenario of vegetables, which is continuously increasing each year with a varying rate except for the years 1980/81 and 1998/99 where it has decreased than the previous year.

During the period of 5 years (2011/12 - 2015/16), solanaceous vegetables has an increasing trend in area, production and yield except for the area under cultivation for eggplant which has declined by $5.2 \%$. Similarly, cruciferous vegetables have an increasing trend in area, production and yield except for the area under cultivation for radish which has declined by $6.0 \%$. Cucurbitaceous vegetables has an increasing trend in area and production while there is an declining trend in yield except for the yield of cucumber which was increased by $15.8 \%$.

In case of other major vegetables, the overall trend for onion is decreasing where area, production and yield has declined by $2.5 \%, 16.7 \%$ and $14.5 \%$ respectively; area under cultivation and production of garlic has increased by $27.7 \%$ and $24.1 \%$ respectively. The area under cultivation for french bean has declined by $25.3 \%$ while production and yield has increased by $64.4 \%$ and $120.1 \%$ respectively.

With the limited area for expansion of cultivation area, increasing the production efficiency is the only way to meet the growing demand of vegetables. Production efficiency can be further enhanced by overcoming several production related barriers such as low scale- lack of commercialization; dependency over traditional crops and local varieties having low yield; inputs and technology associated constraints, etc. Overall vegetable sector development requires efforts to enhance post harvest operation to reduce the post-harvest losses and enhance value chain with a major concern on value addition of vegetables.

\section{Appendix}

\begin{tabular}{lllllll}
\hline Fiscal Year & Area (ha.) & $\begin{array}{l}\text { \% Change in } \\
\text { Area }\end{array}$ & $\begin{array}{l}\text { Production } \\
\text { (Mt.) }\end{array}$ & $\begin{array}{l}\text { \% Change in } \\
\text { Production }\end{array}$ & $\begin{array}{l}\text { Yield } \\
\text { (Mt./ha.) }\end{array}$ & $\begin{array}{l}\text { \% Change in } \\
\text { Yield }\end{array}$ \\
\hline $1977 / 78$ & 88000 & & 466000 & & 5.3 &
\end{tabular}




\begin{tabular}{|c|c|c|c|c|c|c|}
\hline $1978 / 79$ & 91000 & 3.4 & 491000 & 5.4 & 5.4 & 1.9 \\
\hline $1979 / 80$ & 96000 & 5.5 & 528000 & 7.5 & 5.5 & 1.9 \\
\hline $1980 / 81$ & 104000 & 8.3 & 521336 & -1.3 & 5.0 & -8.9 \\
\hline $1981 / 82$ & 118172 & 13.6 & 625099 & 19.9 & 5.3 & 5.5 \\
\hline $1982 / 83$ & 125693 & 6.4 & 667789 & 6.8 & 5.3 & 0.4 \\
\hline $1983 / 84$ & 130162 & 3.6 & 700334 & 4.9 & 5.4 & 1.3 \\
\hline $1984 / 85$ & 138200 & 6.2 & 743000 & 6.1 & 5.4 & -0.1 \\
\hline $1985 / 86$ & 138586 & 0.3 & 782534 & 5.3 & 5.6 & 5.0 \\
\hline $1986 / 87$ & 138964 & 0.3 & 838948 & 7.2 & 6.0 & 6.9 \\
\hline $1987 / 88$ & 139500 & 0.4 & 874523 & 4.2 & 6.3 & 3.8 \\
\hline $1988 / 89$ & 140033 & 0.4 & 922118 & 5.4 & 6.6 & 5.0 \\
\hline $1989 / 90$ & 140524 & 0.4 & 967167 & 4.9 & 6.9 & 4.5 \\
\hline 1990/91 & 140500 & 0.0 & 1074648 & 11.1 & 7.6 & 11.1 \\
\hline $1991 / 92$ & 140500 & 0.0 & 1127840 & 4.9 & 8.0 & 4.9 \\
\hline $1992 / 93$ & 140500 & 0.0 & 1179000 & 4.5 & 8.4 & 4.5 \\
\hline $1993 / 94$ & 140500 & 0.0 & 1197496 & 1.6 & 8.5 & 1.6 \\
\hline $1994 / 95$ & 140500 & 0.0 & 1211507 & 1.2 & 8.6 & 1.2 \\
\hline $1995 / 96$ & 144368 & 2.8 & 1327298 & 9.6 & 9.2 & 6.6 \\
\hline $1996 / 97$ & 146503 & 1.5 & 1357435 & 2.3 & 9.3 & 0.8 \\
\hline $1997 / 98$ & 149979 & 2.4 & 1449742 & 6.8 & 9.7 & 4.3 \\
\hline $1998 / 99$ & 140177 & -6.5 & 1342567 & -7.4 & 9.6 & -0.9 \\
\hline $1999 / 00$ & 149030 & 6.3 & 1489665 & 11.0 & 10.0 & 4.4 \\
\hline $2000 / 01$ & 157162 & 5.5 & 1652979 & 11.0 & 10.5 & 5.2 \\
\hline $2001 / 02$ & 161048 & 2.5 & 1738086 & 5.1 & 10.8 & 2.6 \\
\hline $2002 / 03$ & 165988 & 3.1 & 1799973 & 3.6 & 10.8 & 0.5 \\
\hline $2003 / 04$ & 172586 & 4.0 & 1890100 & 5.0 & 11.0 & 1.0 \\
\hline $2004 / 05$ & 180823 & 4.8 & 2065193 & 9.3 & 11.4 & 4.3 \\
\hline $2005 / 06$ & 189864 & 5.0 & 2190122 & 6.0 & 11.5 & 1.0 \\
\hline $2006 / 07$ & 191922 & 1.1 & 2298689 & 5.0 & 12.0 & 3.8 \\
\hline $2007 / 08$ & 208108 & 8.4 & 2538904 & 10.5 & 12.2 & 1.9 \\
\hline $2008 / 09$ & 225154 & 8.2 & 2754406 & 8.5 & 12.2 & 0.3 \\
\hline $2009 / 10$ & 235098 & 4.4 & 3003821 & 9.1 & 12.8 & 4.4 \\
\hline 2010/11 & 244102 & 3.8 & 3203563 & 6.6 & 13.1 & 2.7 \\
\hline $2011 / 12$ & 245036 & 0.4 & 3298816 & 3.0 & 13.5 & 2.6 \\
\hline $2012 / 13$ & 246392 & 0.6 & 3301684 & 0.1 & 13.4 & -0.5 \\
\hline $2013 / 14$ & 256442 & 4.1 & 3440722 & 4.2 & 13.4 & 0.1 \\
\hline $2014 / 15$ & 266937 & 4.1 & 3580085 & 4.1 & 13.4 & 0.0 \\
\hline $2015 / 16$ & 250150 & -6.3 & 3700969 & 3.4 & 14.8 & 10.3 \\
\hline $2016 / 17$ & 284135 & 13.6 & 3859492 & 4.3 & 13.6 & -8.2 \\
\hline
\end{tabular}

(Source: Vegetable Development Directorate, 2014/15 \& MoAD 2017/18)

Appendix 1. Area, production and yield of Vegetables in Nepal from 1977/78 to 2016/17 


\begin{tabular}{|c|c|c|c|c|c|c|}
\hline \multirow[t]{2}{*}{ Vegetables } & \multirow[t]{2}{*}{ Parameters } & \multicolumn{5}{|l|}{ Year } \\
\hline & & 2011/12 & $2012 / 13$ & $2013 / 14$ & $2014 / 15$ & $2015 / 16$ \\
\hline \multicolumn{7}{|c|}{ Family: Solanaceae } \\
\hline \multirow[t]{3}{*}{ Tomato } & Area (ha) & 17538 & 19728 & 17273 & 19725 & 20046 \\
\hline & Production (Mt) & 282481 & 298594 & 232897 & 331736 & 386824.6 \\
\hline & Yield (Mt/ha) & 16.1 & 15.1 & 13.5 & 16.8 & 19.3 \\
\hline \multirow[t]{3}{*}{ Egg Plant } & Area (ha) & 9157 & 9276 & 8352 & 9231 & 8680.4 \\
\hline & Production (Mt) & 121806 & 124669 & 119528 & 131405 & 128029.5 \\
\hline & Yield (Mt/ha) & 13.3 & 13.4 & 14.3 & 14.2 & 14.7 \\
\hline \multirow{3}{*}{ Chilli } & Area (ha) & 7538 & 8908 & 7666 & 8239 & 9580.8 \\
\hline & Production (Mt) & 55839 & 53688 & 61686 & 74902 & 95931.2 \\
\hline & Yield (Mt/ha) & 7.4 & 6.0 & 8.0 & 9.1 & 10.0 \\
\hline \multirow{3}{*}{ Capsicum } & Area (ha) & 1062 & 1112 & 1318 & 1114 & 1183.8 \\
\hline & Production (Mt) & 10499 & 10587 & 14216 & 11516 & 12369.3 \\
\hline & Yield (Mt/ha) & 9.9 & 9.5 & 10.8 & 10.3 & 10.4 \\
\hline \multicolumn{7}{|c|}{ Family: Cruciferae } \\
\hline \multirow[t]{3}{*}{ Cauliflower } & Area (ha) & 32630 & 34065 & 33880 & 34704 & 34967 \\
\hline & Production (Mt) & 491834 & 524205 & 352535 & 494765 & 550044.8 \\
\hline & Yield (Mt/ha) & 15.1 & 15.4 & 10.4 & 14.3 & 15.7 \\
\hline \multirow[t]{3}{*}{ Cabbage } & Area (ha) & 27916 & 27445 & 27026 & 27679 & 28071.4 \\
\hline & Production (Mt) & 448980 & 468284 & 370660 & 453600 & 484036.8 \\
\hline & Yield (Mt/ha) & 16.1 & 17.1 & 13.7 & 16.4 & 17.2 \\
\hline \multirow[t]{3}{*}{ Radish } & Area (ha) & 17998 & 18415 & 18190 & 18188 & 16915.7 \\
\hline & Production (Mt) & 262203 & 266112 & 272152 & 263215 & 268119.6 \\
\hline & Yield (Mt/ha) & 14.6 & 14.5 & 15.0 & 14.5 & 15.9 \\
\hline \multicolumn{7}{|c|}{ Family: Cucurbitaceae } \\
\hline \multirow[t]{3}{*}{ Bottle Gourd } & Area (ha) & 6206 & 5933 & 6472 & 7207 & 8611.5 \\
\hline & Production (Mt) & 102750 & 97155 & 102809 & 108208 & 129798.1 \\
\hline & Yield (Mt/ha) & 16.6 & 16.4 & 15.9 & 15.0 & 15.1 \\
\hline \multirow[t]{3}{*}{ Bitter Gourd } & Area (ha) & 6453 & 6426 & 7047 & 8113 & 10082.2 \\
\hline & Production (Mt) & 88937 & 89053 & 100961 & 112309 & 132350.1 \\
\hline & Yield (Mt/ha) & 13.8 & 13.9 & 14.3 & 13.8 & 13.1 \\
\hline \multirow[t]{3}{*}{ Cucumber } & Area (ha) & 8500 & 8970 & 8789 & 9708 & 9396.8 \\
\hline & Production (Mt) & 124262 & 127918 & 129266 & 150051 & 159041.8 \\
\hline & Yield (Mt/ha) & 14.6 & 14.3 & 14.7 & 15.5 & 16.9 \\
\hline \multirow{3}{*}{ Pumpkin } & Area (ha) & 6336 & 6136 & 6733 & 7380 & 7203.4 \\
\hline & Production (Mt) & 92773 & 91961 & 97569 & 106547 & 103169.6 \\
\hline & Yield (Mt/ha) & 14.6 & 15.0 & 14.5 & 14.4 & 14.3 \\
\hline \multicolumn{7}{|c|}{ Family: Others (Amaryllidaceae, Leguminosae, Malvaceae) } \\
\hline \multirow[t]{3}{*}{ Onion } & Area (ha) & 20593 & 17740 & 18698 & 20712 & 20070 \\
\hline & Production (Mt) & 286467 & 245102 & 242675 & 248584 & 238590.7 \\
\hline & Yield (Mt/ha) & 13.9 & 13.8 & 13.0 & 12.0 & 11.9 \\
\hline Garlic & Area (ha) & 5911 & 5904 & 6569 & 7119 & 7551 \\
\hline & Production (Mt) & 40630 & 40757 & 45035 & 44723 & 50426 \\
\hline & Yield (Mt/ha) & 6.9 & 6.9 & 6.9 & 6.3 & 6.7 \\
\hline Cowpea & Area (ha) & 4224 & 4273 & 4086 & 4599 & 4620.7 \\
\hline & Production (Mt) & 35223 & 37149 & 38523 & 45287 & 56790.1 \\
\hline & Yield (Mt/ha) & 8.3 & 8.7 & 9.4 & 9.8 & 12.3 \\
\hline French Bean & Area (ha) & 3841 & 1594 & 2044 & 2087 & 2869.8 \\
\hline & Production (Mt) & 15177 & 14210 & 16087 & 18688 & 24953.3 \\
\hline & Yield (Mt/ha) & 4.0 & 8.9 & 7.9 & 9.0 & 8.7 \\
\hline Okra & Area (ha) & 9609 & 9619 & 10600 & 10613 & 10781.4 \\
\hline & Production (Mt) & 108806 & 109268 & 120660 & 118585 & 122101.6 \\
\hline & Yield (Mt/ha) & 11.3 & 11.4 & 11.4 & 11.2 & 11.3 \\
\hline
\end{tabular}

Appendix 2. Area, production and yield of some major vegetables in Nepal from 2011/12 to 2015/16

\section{Authors' Contributions}

The article is the outcome of collective work of all the authors. Author DG designed the study, performed the statistical analysis, wrote the protocol and wrote the first draft of the manuscript. Authors GL and BP managed the analysis of the study. Authors SK and BB managed the literature searches. All authors read and approved the final manuscript.

\section{Conflict of Interest}

No conflict of interest was reported by the authors. 


\section{References}

1. Annual Progress Report. Government of Nepal, Ministry of Agricultural Development (MOAD), Agri-Business Promotion and Statistics Division, Singhdurbar, Kathmandu, 2015.

2. Karki YK. Nepal Portfolio Performance Review (NPPR), Ministry of Agriculture Development (MoAD), Kathmandu, 2015.

3. Agriculture Diary. Agriculture Information \& Communication Center, Ministry of Agricultural Development, Government of Nepal, Harihar Bhawan, Lalitpur, 2015.

4. Pandey G, Basnet S, et al. An Analysis of Vegetables and Fruits Production Scenario in Nepal. Asian Research Journal of Agriculture 2017; 6(3): 1-10. http://DOI: 10.9734/ARJA/2017/36442.

5. National Sample Census of Agriculture 2011/12. Central Bureau of Statistics, Kathmandu, Nepal, 2013.

6. Statistical Information of Nepalese Agriculture (SINA). Government of Nepal, Ministry of Agricultural Development, Agri-Business Promotion and Statistics Division, Singhdurbar, Kathmandu, 2015/16.

7. Value Chain/ Market Analysis of the Off Season Vegetable Sub-Sector in Nepal. Nepal Economic Agriculture, and Trade Activity/ USAID, August 2011. Available at: http://www.ansab.org/wp-content/uploads/2011/09/Nepal_NEAT_Subsector-Market-Analysis-Off-Season-Vegetabl e_Aug_2011.pdf.

8. Agriculture Development Strategy (ADS). Draft Vision Report, Government of Nepal, Ministry of Agricultural Development, Singhdurbar, Kathmandu, 2015. 